\title{
Eggshell calcification in a case of longstanding hydrocele
}

\author{
Apul Goel, Pavan Kumar, Mayank Jain, Gyanendra Singh
}

Urology, King George's Medical University, Lucknow, Uttar Pradesh, India

Correspondence to Dr Pavan Kumar; pavan53rame@gmail.com

Accepted 11 December 2019

\section{DESCRIPTION}

An 80-year-old man was being evaluated for voiding luts with haematuria. On physical examination, he was found to have grossly enlarged right testis which was stony hard on palpation with normal left testis (figure 1). On radiological evaluation, he was found to have grossly enlarged right hemiscrotum with peripheral calcifications measuring $(36 \times 76 \times 86 \mathrm{~mm})$ in right scrotal sac (figure 2).

A hydrocele is an abnormal fluid collection within the tunica vaginalis of the scrotum. Calcification of hydrocele sac is a rare complication. ${ }^{1}$ In 1935, published case by Kickham CJE 'Calcified hydrocele of the tunica vaginalis testis: case report' was the first reported case of calcified hydrocele sac. He found intraoperatively $15 \mathrm{cc}$ milky fluid in hydrocele sac and calcified wall of hydrocele sac.

According to 2019 WHO update of lymphatic filariasis, the global baseline estimate of people affected by lymphatic filariasis was 25 million men with hydrocele and over 15 million people with lymphoedema. ${ }^{2}$ Lymphatic filariasis is infection with the filarial worms, Wuchereria bancrofti, Brugia malayi or B timori. These parasites are transmitted to humans through the bite of an infected mosquito and develop into adult worms in the lymphatic vessels, causing severe

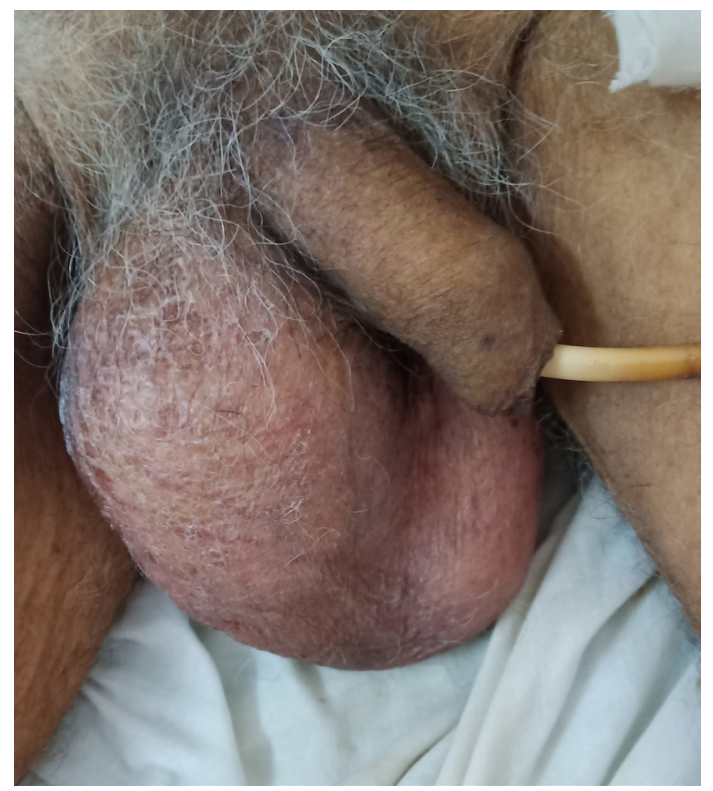

Figure 1 Physical examination shows stony hard enlarged right testis.
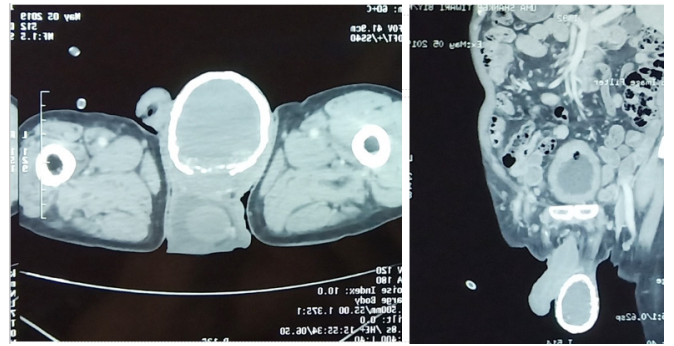

Figure 2 Contrast enhanced computed tomography (CECT) showing peripheral calcifications within right scrotal sac.

damage and swelling (lymphoedema). Elephantiasis-painful, disfiguring swelling of the legs and genital organs-is a classic sign of late-stage disease. $^{3}$

Filariasis is endemic in India and contributes about $40 \%$ of the total global burden. ${ }^{4}$ Recurring attacks of epididymo-orchitis resulting from filariasis may lead to hydrocele formation. After the early episodes, the swelling around the testis disappears completely, but over the years the tunica vaginalis becomes thickened and there is progressive enlargement of the hydrocele. Rarely, longstanding hydrocele undergoes calcification over its surface. ${ }^{5} 6$ In endemic areas, differentiation of filarial from idiopathic hydrocele is difficult. $^{7}$ Discovery of a thick, fibrous tunica, especially with cholesterol or calcium deposits, should suggest a diagnosis of filariasis. ${ }^{7}$ Tunical calcification is very rare in idiopathic hydrocele.

The infection can be treated with drugs. However, chronic conditions may not be curable by antifilarial drugs and require other measures, for example, surgery for hydrocele, care of the skin and exercise to increase lymphatic drainage in lymphoedema.

Annual treatment of all individuals at risk (individuals living in endemic areas) with recommended

\section{Learning points}

- Eggshell calcification of scrotum is a rare entity, it indicates a state of chronic infection within the hydrocele sac.

- In endemic areas, filariasis is the most common cause of hydrocele.

- Discovery of a thick, fibrous tunica, especially with cholesterol or calcium deposits, should suggest a diagnosis of filariasis. 
antifilarial drugs combination of either diethyl-carbamazine citrate (DEC) and albendazole or ivermectin and albendazole; or the regular use of DEC fortified salt can prevent occurrence of new infection and disease. ${ }^{3}$

Contributors PK: conception and conduct, acquisition of data. AG: analysis and interpretation, reporting. MJ: literature review. GS: critical review.

Funding The authors have not declared a specific grant for this research from any funding agency in the public, commercial or not-for-profit sectors.

Competing interests None declared.

Patient consent for publication Obtained.

Provenance and peer review Not commissioned; externally peer reviewed.

\section{REFERENCES}

1 Russell RCG, Williams NS, Christopher JK. Bulstrode: Baileys and Loves short practice of surgery, international Student's edition, and 2004. 1408. 24 edition.

2 World health organisation update on filariasis, 2019. Available: https://www.who.int/ news-room/fact-sheets/detail/lymphatic-filariasis

3 World health organisation update on filariasis, 2019. South East Asian Region. Available: https://www.who.int/lymphatic_filariasis/en/

4 Pani SP, Kumaraswami V, Das LK. Epidemiology of lymphatic filariasis with special reference to urogenital-manifestations. Indian J Urol 2005;21:44-49.

5 Amorone Leiva JL, Puscinski AJ, Gallego D, et al. [Calcification of the tunica vaginalis testis]. Arch Esp Urol 2002;55:208-9.

6 Virseda Rodríguez JA, Hernández Millán I, Segura Martín M. [Calcification of the tunica vaginalis]. Arch Esp Urol 1997;50:406-7.

7 McAleer SJ, Johnson CW, Johnson WD.In Wein AJ, Kavoussi LR, Novik AC, eds. Tuberculosis and parasitic and fungal infections of the genitourinary system. Philadelphia: Saunders Elsevier, 2007: 436-70.

Copyright 2020 BMJ Publishing Group. All rights reserved. For permission to reuse any of this content visit

https://www.bmi.com/company/products-services/rights-and-licensing/permissions/

BMJ Case Report Fellows may re-use this article for personal use and teaching without any further permission.

Become a Fellow of BMJ Case Reports today and you can:

- Submit as many cases as you like

- Enjoy fast sympathetic peer review and rapid publication of accepted articles

- Access all the published articles

Re-use any of the published material for personal use and teaching without further permission

Customer Service

If you have any further queries about your subscription, please contact our customer services team on +44 (0) 2071111105 or via email at support@bmj.com.

Visit casereports.bmj.com for more articles like this and to become a Fellow 